2013s-16

\title{
Vocationalization in the research intensive university
}

Manuel Crespo, Houssine Dridi, Marie Lecomte

\begin{tabular}{c}
\hline Série Scientifique \\
Scientific Series
\end{tabular}

\section{Montréal \\ Juin 2013}

(C) 2013 Manuel Crespo, Houssine Dridi, Marie Lecomte. Tous droits réservés. All rights reserved. Reproduction partielle permise avec citation du document source, incluant la notice (C).

Short sections may be quoted without explicit permission, if full credit, including (C) notice, is given to the source.
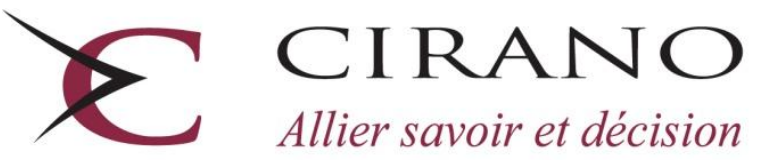

Allier savoir et décision

Centre interuniversitaire de recherche en analyse des organisations 


\section{CIRANO}

Le CIRANO est un organisme sans but lucratif constitué en vertu de la Loi des compagnies du Québec. Le financement de son infrastructure et de ses activités de recherche provient des cotisations de ses organisations-membres, d'une subvention d'infrastructure du Ministère du Développement économique et régional et de la Recherche, de même que des subventions et mandats obtenus par ses équipes de recherche.

CIRANO is a private non-profit organization incorporated under the Québec Companies Act. Its infrastructure and research activities are funded through fees paid by member organizations, an infrastructure grant from the Ministère du Développement économique et régional et de la Recherche, and grants and research mandates obtained by its research teams.

\section{Les partenaires du CIRANO}

\section{Partenaire majeur}

Ministère de l'Enseignement supérieur, de la Recherche, de la Science et de la Technologie

Partenaires corporatifs

Autorité des marchés financiers

Banque de développement du Canada

Banque du Canada

Banque Laurentienne du Canada

Banque Nationale du Canada

Banque Scotia

Bell Canada

BMO Groupe financier

Caisse de dépôt et placement du Québec

Fédération des caisses Desjardins du Québec

Financière Sun Life, Québec

Gaz Métro

Hydro-Québec

Industrie Canada

Investissements PSP

Ministère des Finances et de l'Économie

Power Corporation du Canada

Rio Tinto Alcan

State Street Global Advisors

Transat A.T.

Ville de Montréal

\section{Partenaires universitaires}

École Polytechnique de Montréal

École de technologie supérieure (ÉTS)

HEC Montréal

Institut national de la recherche scientifique (INRS)

McGill University

Université Concordia

Université de Montréal

Université de Sherbrooke

Université du Québec

Université du Québec à Montréal

Université Laval

Le CIRANO collabore avec de nombreux centres et chaires de recherche universitaires dont on peut consulter la liste sur son site web.

Les cahiers de la série scientifique (CS) visent à rendre accessibles des résultats de recherche effectuée au CIRANO afin de susciter échanges et commentaires. Ces cahiers sont écrits dans le style des publications scientifiques. Les idées et les opinions émises sont sous l'unique responsabilité des auteurs et ne représentent pas nécessairement les positions du CIRANO ou de ses partenaires.

This paper presents research carried out at CIRANO and aims at encouraging discussion and comment. The observations and viewpoints expressed are the sole responsibility of the authors. They do not necessarily represent positions of CIRANO or its partners. 


\title{
Vocationalization in the research intensive university
}

\author{
Manuel Crespo ${ }^{*}$,Houssine Dridi ${ }^{*}$, Marie Lecomte ${ }^{*}$
}

\section{Résumé / Abstract}

This paper analyses the trends in program creation, modification and abolition/suspension, during a ten year period, of three research intensive universities in Canada: Universite de Montréal, Université Laval, and McGill University. The trends observed, by analysing the Minutes of the Commission des études in the case of Francophone universities and the 'Senate Subcommittee on Teaching and Programs' for McGill University, reveal a tendency toward vocationalization when changes are introduced in the academic programs supply. Data from 25 interviews of professors involved in university-industry collaborative research projects, conducted between April and June of 2007 in McGill University and University of British Columbia show also a tendency towards an utilitarian graduate training. Values of practicality, collaboration, interdisciplinarity and entrepreneurship, resulting from professors' bisectorial and multisectorial collaborations with industry, are passed on to students, particularly graduate students.

Mots clés/keywords : Vocationalization of higher education, vocational drift, graduate training, market demands, academic programs change, research intensive university.

\footnotetext{
*Emeritus Professor Université de Montréal, manuel.crespo@umontreal.ca

† Professor, Université du Québec à Montréal.

${ }^{\sharp}$ Research Assistant, Université de Montréal.
} 
From a historical perspective, the differentiation of higher education institutions became a priority in the 1950s and 1960s when public control agencies were developed as a response to the explosion of enrollment in that sector (Bastedo \& Gumport, 2003). Thus, starting at the middle of the 20th Century, the profile of different higher education systems experienced major changes at the structural level as well as at the level of training programs supply and student body composition. The California Master Plan at the beginning of the 1960s (Kerr, 1963; Smelser 1974) and the binary systems (university/non-university post-secondary institutions) of several European countries (Polytechnics in the UK, Diplomi universitari in Italy, Hogescholen in the Netherlands, see Barone \& Ortiz, 2011) are examples of the changing profiles of higher education systems. This trend was also present in Canada where a post-secondary non-university sector was created in the late sixties in several Canadian provinces (Collèges d'enseignement général et professionnel in Québec and non-university colleges in the other provinces. See Gallager, 1990).

Several factors may explain the dynamics of differentiation. In Europe, in addition to the exponential growth in enrollments in higher education, the Bologna process, an interstate regulation mechanism, works as a complement to horizontal diversity by favoring a vertical diversity (Barone \& Ortiz, 2011). For Kitagawa \& Oba (2010), the analysis of the Japanese situation shows that the strategic allocation of resources at institutional level is a key factor for the management of system differentiation. A quasi market context is also invoked as a factor that increases system differentiation (see Meek, Godegebuure \& Huisman, 2000; Teixeira et al., 2004, Teixeira et al., 2012).

In Canada, several authors have identified "academic capitalism" (Slaughter \& Leslie, 1997) as a plausible explanation of increasing diversity (see Dennison \& Schuetze, 2004; Jones, 2004; Levin, 2004; Marshall, 2004, 2008; Skolnik, 2004; Cudmore, 2005). For Fisher et al. (2009), there seems to be favourable conditions in Alberta and British Columbia for the emergence of quasi markets in higher education which may impact on the increasing of its diversity. 
These varied systemic forms had supposedly positive return: accrued number of learning options, better adaptation to societal changes, less risk of losing students on behalf of other higher education systems, and better adaptation to market needs (Ayalon \& Yoger, 2005; Arum et al. 2007; Van Vucht, 2008; Morphew, 2009).

Nevertheless, the issue of a real diversity remains at the center of researchers' interest. In effect, one may ask the question whether the visible forms of diversity may be rather nominal, the strong tendency of systems leading, on the contrary, to an uniformization or homogenization of organizational arrangements. Birbaum's study on the diversity of colleges and universities in the United States between 1960 and 1980 shows that there has been no real increase in the diversity of the system, in spite of the unprecedented growth of higher education in that country during that period (Birbaum, 1983). Morphew, (2009) draws a similar conclusion in his analysis of the development of higher education in the fifty American states between 1972 and 2002.

Teichler (2008) notes a recurrent movement pushing low status institutions to imitate the behavior of high status institutions. Bastedo \& Gumport (2003) also identified mimetic behaviors amongst institutions, in spite of their structural differences. According to them, even in American States having Master Plans that specify a work division and particular responsibilities for their higher education institutions, colleges and universities were able to develop a range of academic programs practically identical from one campus to the other (Bastedo \& Gumport, 2003, p. 343). In the Canadian scene, Fisher et al. (2009) note that there is a tendency toward vocationalization in the university sector which coincides with a certain drift in the collegial sector, institutions of this latter sector seeking to imitate universities, notably by asking provincial governments the right to grant degrees.

Several of the countries with binary systems (e.g. UK, Australia, Israel) have reverted to a unified higher education system and interpretations are numerous about this change. Teichler (2006) suggested that the setting aside of binary systems reveals the failure of national policies of diversification. As for Bleiklie (2005), he analyses the question of convergence of higher education systems as a response to the society of knowledge. He discusses the issues of hierarchization and specialization within higher education systems 
and shows that, although there are specific ways of realizing convergence (accrediting a path dependency component), the differences between vocational training corresponding to what he calls 'knowledge as outcome' - and scientific disciplinary training are blurred. Even in research universities, the tendency towards the development of utility-oriented, applied research and vocationally-oriented education programs is found. He asserts that: "[...] as the scientific core expands, it becomes 'diluted' and infused with 'social', more utilitarian demands and needs" (p. 49).

This study tackles the issue of convergence in higher education systems exclusively from the university sector side. Its aim is to explore if there is a trend, in some selected Canadian research intensive universities, towards vocationalization in academic programs and graduate training ${ }^{1}$.

Teichler (2001) has observed, in the university sector, what Williams (1985) had called a "vocational drift". He defines this phenomenon as a tendency, found in a growing number of universities, to become more applied, as a way of increasing their graduates' chances of employment, thus imitating the behaviour of institutions of the non-university sector. The vocationalization of university has its roots, according to Barnett (1990), in industry's demand for graduates with more work-related skills. Barnett (1990) explained the phenomenon, from a sociological point of view, as a loss of academic autonomy resulting from the increased influence of State, industry and other agencies over what goes on in universities. Further along, Kogan (2006) comments on the practical orientation or, in Brint's terms, the "utilitarian ethos" (Brint, 2002), found in many universities, using the concept of "externalization" of control exercised over academic productivity by systems of accountability, evaluation and performance. As far as Neave (2006) is concerned, the Post-Bologna university is the product of two remarkable displacements: trickling into the university, stricto sensu, of a vocational mission and a logical extension of "vocationalism" into the domains of research and research training. Brint (2002) adds to this that the Bologna Declaration uses a language that underlines the

1 This study is part of a larger study of the vocationalization of Canadian higher education funded by the Social Sciences and Humanities Research Council of Canada (410-2005-0651). 
role of university in ensuing economic strength and competitiveness through the production of skilled workers.

Frank Rhodes, President emeritus of Cornell University, identified a tendency, already noticeable at the end of the nineties, towards a shrinking of liberal education in the United States. According to him, whereas in 1968, 47\% of first degree graduates were from the liberal arts sectors, twenty years later, the percentage dropped to $27 \%$ in favour of vocational (professional) degrees (Rhodes, 2001). This data is corroborated by Grubb \& Lazerson (2005) who note that at the beginning of the 21 st Century, at least two thirds of first degree students enrolled in American universities were from the professional (vocational) sectors, and their goals for future studies were clearly vocational. Moreover, according to them, the growth of education sectors in the last decades has taken place principally in occupational domains including management, the health professions, biology, computer sciences and specific aspects of recreational studies. As for the liberal arts sector, it has remained stable. Brint (2002) also stresses that, in a period when total growth experienced by the system was a remarkable 50\%, the Liberal Arts sector decreased in absolute terms. Brint et al. (2005) report detailed data that support this trend toward vocationalization. Thus, during the last 30 years, there has been, in the United States, a progressive reduction of the proportional part of liberal arts education in first degree programs. Whereas in 1960, 45\% of first degree graduates had a vocational content, the percentage today is around $60 \%$. In fact, hundreds of institutions grant $80 \%$ and more degrees in the vocational/professional sectors (Brint, 2001).

Eicher (1999) estimated in the French context, at the beginning of this century, at around 600000 , the number of students enrolled in professional programs outside university (29\% of total enrolment) and he evaluated at 220000 the number of students registered in professional programs in the university sector (10\% of total enrolment) [see also Eicher, 2001]. Powell et al. (2012) also report the creation of professional B.As in France (licences professionnelles) as an example, in their terms, of the "vocationalization of higher education" (p. 410). Since 1999, around 1600 vocational B.A. programs have been established attracting approximately 40,000 students. The new B.A. programs in Germany appear to be modeled by the 'Berufsprinzip', the vocational principle central to 
German conceptions of skill formation, in as much as these new programs lead to a specific higher education degree offering full vocational qualification (see Powel et al., 2012).

McLaughlin \& Mills (2011) analyse a project of collaboration between institutions of vocational education and training (VET) and higher education institutions (HE) that led to a dual parallel qualification. In 2009-2010, construction management students graduated with this dual qualification. Powell, Bernhard \& Graf (2012) document the impact of the emerging European model of education more sensitive to employability and market demands as a result of the Bologna and Copenhagen process (see also Bash, 2009).

In the Canadian context, Smith (2005) reported on trends in the creation of new university programs in Manitoba (Canada) in a period of 35 years (divided in two 17 year periods before and after 1984-1985). If one considers all 35 years, there isn't much difference between Liberal Arts programs (33.1\%), Applied programs (34.5\%) and Mixed programs (32.4\%). However, after 1984-1985, the trend is toward Applied and Mixed programs and away from Liberal Arts programs [28.8\% Liberal Arts, 35.0\% Applied and 36.3\% Mixed (p. 121)]. Côté \& Allhar (2011) note also the same tendency in Ontario where, according to them, universities insist more on training than on education. They severely criticize this tendency which they attribute to the corporatization of university in response to market demands. From the demand side, data gathered by the senior author, show an increase in the relative proportion of students choosing "nonapplied/non- professional" programs. If one considers the Top 10 Canadian universities, between 1989 and 1999, there has been an increase of 11.5\% in students opting for applied/professional programs and a decrease of $7.5 \%$ in students opting for "nonapplied/non-professional” programs in Bachelor's degree programs. More recent data from three research universities in Québec (1996-2005) also show this tendency with regards not only to Bachelor's programs but also to Graduate programs (see Crespo, 2006). This tendency might be explained, at least partially, by the rewards of the market for professional/vocational programs. Adamuti-Trache et al. (2006) show, in the Canadian context, that "labour market outcomes like employment status and income 
point toward a net advantage of being a graduate of an applied program" (p. 67) [see also Walters, 2006].

Qualitative data tend to confirm the tendency revealed by quantitative data. In the senior author's own university, a few years ago, a first degree program was created in "security and police matters". At University of Ottawa, there is a first degree program in "applied sciences". Several American universities have first degree programs that are highly vocational, programs like "usability engineering" dealing with the relationship between computer and man. Other programs are simply astonishing. This is the case of some Boston University first degree certificates in "medical and legal interpretation", "real estate" and "technological entrepreneurship".

With regards to graduate training, some studies report evidence of a vocational drift. Graduate students are often trained within research projects financed by industry. Data reported by Thune (2009) show that some $20 \%$ of graduate students had collaborated with industry during their doctoral studies. For this author, graduate students are central to the production and transfer of knowledge and for the formation and maintenance of network ties between universities and firms. Kyvik \& Olsen (2008) also insist on the role of graduate students as producers of new knowledge. Graduate students are sometimes considered as "cheap labor", since they are asked to develop aspects of the research project at low pay (Slaughter, Archerd \& Campbell, 2004). However, they benefit from the interaction with industry: development of a scientific and business network which help in making a smooth transition from university to industrial laboratories (Crespo \& Dridi, 2007), adoption of an efficient way of delivering research results, opportunities of being part of a "spin-off" with the prospect of future economic gains, and others. The survey conducted by Bienkowska \& Klofsten of Ph.D. students of a Swedish university shows that the majority of respondents were engaged in collaboration with external organizations and that students from all faculties were on average interested in commercialisation and in favor of it (Bienkowska \& Klofsten, 2012). Although they may be some dysfunctions of graduate training in a university-industry research project, such as secrecy and delay in publishing results, the balance is rather positive. Professors try to cope with these dysfunctions using "sequencing" and "sanitising" strategies (Slaugher et 
al., 2002), the former consisting in timing patenting and publication to minimize conflicts with industry, the latter aiming at removing whatever numbers or data the company might find objectionable. When there are potential dilemmas with respect to rights of graduate students in a collaborative project with industry, both academic and industrial supervisors try to solve it in a way that does not cause prejudice to the students (Salminen-Karlsson \& Wallgren (2008). From students' point of view, the role of advisors in industrial applied research projects is assessed positively: "students believe that advisors successfully achieve meeting sponsors' demands and commitments without encompassing the training and creativity of graduate students" (Mendoza, 2007, p. 84). Although professors were aware that they benefited from cheap labor, Slaughter, Archerd \& Campbell (2004) affirm that they valued graduate students primarily as apprentices and future colleagues. Finally, Barrell-Damian et al. (2010), assessing a pan-European collaborative (university-industry) doctoral training, reported that they did not find evidence suggesting that academic standards should be compromised for an effective collaborative doctoral education. This is one good example of new modes of graduate training that better fits the present competency demands (see Gemme \& Gingras 2004; Enders, 2005).

Within this broad empirical and theoretical context of the "vocationalization" of university education, this paper has then a twofold objective. First, it analyses the trends in program creation, abolition/suspension and modification in a longitudinal (ten years) comparative perspective in Quebec's higher education context. Second, it explores, in a comparative national perspective, how graduate students are trained in research. This twofold objective aims at understanding the phenomenon of vocationalization of the university from the supply side, in terms of both: a) academic programs, and b) research training.

\section{METHODOLOGICAL NOTE}

The research consists of case studies of four research intensive universities in Canada: two Anglophone and two Francophone universities. The two Francophone universities are Université de Montréal and Université Laval. The two Anglophone universities are 
McGill University and University of British Columbia. These four institutions are classified among the 10 top research universities in Canada ${ }^{2}$.

The data were gathered through a meticulous content analysis of Senate Minutes (Minutes of the Senate Subcommittee on Teaching and Programs -SCTP- at McGill University) $^{3}$ or the equivalent (in the cases of Université de Montréal and Université Laval the appropriate source of data were the Minutes of the Studies Commission or Commission des études).

The period analysed is 1996 to 2005 in the case of Université de Montréal, 1996-2006 in the case of Universite Laval, and 1997 to 2007 in the case of McGill University. All program changes pertaining to "creation", "modification" and "abolition/suspension" were carefully reviewed to determine whether the changes were in the direction of increased vocationalization or response to market needs. Contrary to the notions of "creation" and "abolition/suspension", which refer to a single program being created or abolished, a particular program can be "modified" more than once. In the calculations below, "modifications" are counted in absolute terms.

The criteria of inclusion for asserting whether the changes point toward an applied or market orientation are the following:

- a response to a demand from the social/professional environment;

- adaptation of the program to suit the nature of the demanding organization;

- adaptation resulting from a market assessment;

- program of specialized training (particularly in the healthcare sectors);

- graduate Certificate or Master's tailored to accommodate special needs;

- collaborative agreement with an external organization (e.g. police, healthcare institutions, etc.).

If the changes are characterized by at least one of these criteria, they are deemed to be "vocationally or market oriented". If they are of a "general education" type (Liberal Arts)

2 Three of these universities, McGill University, University of British Columbia, and Université de Montréal are among the top one hundred universities worldwide according to the World University Rankings by The Times Higher Education (2012).

3 The SCTP Minutes for McGill University can be found at http://www.mcgill.ca/sctp/minutes. 
but with some "applied" aspects, they are considered to be "mixed". Thus, three categories of program changes were constructed with regard to vocational/market orientation: non-applied/non-vocational, mixed (applied/vocational aspects with nonapplied/liberal education aspects), and applied/vocational.

In addition to the content analysis of the Minutes of the Commission des études of the Universities of Montréal and Laval and the SCTP Minutes at McGill University, 25 interviews were conducted with professors in both Anglophone universities of the study: McGill University and University of British Columbia. The interviews were semistructured and lasted for around one hour to one hour and a half. Some interviewees were contacted more than once for certain clarifications. The interviews were conducted in April, May and June 2007. The main purpose of the interviews was to know how graduate students are trained. Are they trained principally in fundamental or in applied research? Are they trained for the market? What is the impact of industry collaboration on academic research?

The professors were selected because of their continuous, important ties with industry and/or research networks where government and industry are both involved as with the Canadian Networks of Centers of Excellence. The professors in the sample are distributed as such:

- Atmospheric and Oceanic Sciences (1)

- Biochemistry (1)

- Biology (1)

- Chemistry (1)

- Civil engineering (1)

- Computer Science (1)

- Electrical engineering (1)

- Environmental engineering (1)

- Environmental Science (1)

- Food chemistry and toxicology (1)

- Law (1)
- Mathematics (1)

- Mechanical Engineering (1)

- Medical genetics (3)

- Microbiology (1)

- Neurology (2)

- Nursing (1)

- Obstetrics (1)

- Pharmacology (1)

- Psychology (1)

- Sociology (1)

- Zoology (1)

Several of these professors are considered "stars" both nationally and internationally. One of the professors, for example, is professor of Biochemistry at McGill University. He has 
created, with one of his colleagues, one of the most successful Biotech companies in Canada. He has led the Institute on Cancer Research (ICR), one of the 13 Canadian Institutes on Health Research (CIHR), a leadership position in Canadian cancer research. Another is professor of Neurology at McGill University, director of the Center for Nerve Cell Survival at Montréal's Neurological Institute (McGill University) and founder in his own right of a successful Biotech Company. A third is professor of Microbiology at University of British Columbia, a leading international figure in the domains of microbiology and immunology, he is also Director of a laboratory that carries his name and conducts a stunning number of cutting edge research projects. These professors are but a few in a series of top level scientists who have contributed, through their generous observations, analyses and comments to our research on vocationalization in the research intensive university.

\section{DATA ANALYSIS}

This section analyses, first, the trends relative to the creation, abolition/suspension and modification of first degree and graduate programs (Diplomas, Master's and Ph.D.) at Université de Montréal (1996-2005), Université Laval (1999-2006) and McGill University (1996-2007). It also discusses research training from professors' perspectives in the two Anglophone universities of the study: McGill University and University of British Columbia.

\section{Trends in program change}

To facilitate the analysis of data, the ten year trends of Université de Montréal, Université Laval and McGill University will be analysed separately, and then, a discussion will follow on the similarity and differences of the respective trends.

\section{Trends at Université de Montréal}

In the period considered and with regards to first degree programs, Université de Montréal created 115 new programs, abolished or suspended enrolment in 31 programs and introduced 101 modifications in its programs. As pertains to $2^{\text {nd }}$ and $3^{\text {rd }}$ cycle programs, this Institution created, in the same period, 185 new programs, abolished or 
suspended enrolment in 11 programs, and introduced 103 modifications in its programs (see table 1).

Table 1 Undergraduate and Graduate program changes at Université de Montréal (1996-2005)

\begin{tabular}{|l|c|c|c|c|}
\hline Program changes & $\begin{array}{c}\text { Non-applied/ } \\
\text { non-vocational } \\
(\%)\end{array}$ & $\begin{array}{c}\text { Mixed } \\
(\%)\end{array}$ & $\begin{array}{c}\text { Applied/ } \\
\text { vocational } \\
(\%)\end{array}$ & \% (N) \\
\hline \multicolumn{5}{|c|}{ Undergraduate Programs } \\
\hline Creation & 35.3 & 21.9 & 42.8 & $100 \%(115)$ \\
\hline Modification & 29.3 & 20.7 & 50.0 & $100 \%(101)$ \\
\hline Abolition/suspension & 23.6 & 17.6 & 58.8 & $100 \%(31)$ \\
\hline \multicolumn{5}{|c|}{ Graduate Programs } \\
\hline Creation & 28.2 & 24.3 & 47.5 & $100 \%(185)$ \\
\hline Modification & 40.0 & 30.0 & 30.0 & $100 \%(103)$ \\
\hline Abolition/suspension & 50.0 & 20.0 & 30.0 & $100 \%(11)$ \\
\hline
\end{tabular}

Whereas $35.3 \%$ of created first-degree programs where of a non-vocational/non-applied nature, $21.9 \%$ were mixed and $42.8 \%$ were applied/vocational. In the case of abolished/suspended programs, $23.6 \%$ of first-degree programs were non-applied/non vocational, $17.6 \%$ were mixed and $58.8 \%$ were applied/vocational. As for modifications in existing first degree programs, $29.3 \%$ of them were of non-applied/non-vocational nature, $50 \%$ were of applied/vocational, and $20.7 \%$ mixed.

If one considers graduate programs $\left(2^{\text {nd }}\right.$ and $3^{\text {rd }}$ cycle programs), of the 185 created programs, $28.2 \%$ were non-applied/non-vocational, $24.3 \%$ were mixed and $47.5 \%$ were applied/vocational. In terms of abolition/suspension, 5 programs, or $50 \%$ of the total abolished/suspended were non-applied/non-vocational, 2 were mixed and 3 were applied/vocational. As pertains to modifications, $40 \%$ of them were of non-applied/nonvocational type, $30 \%$ were mixed and $30 \%$ were of applied/vocational type.

Is there a vocationalization trend at Université de Montréal? The answer is resolutely yes with regards to program creation and modification. Around two thirds of program creations and modifications were of applied/vocational or mixed programs. One would expect that this trend would be reversed with respect to abolitions/suspensions of 
programs: in other words, there would be much more abolitions/suspensions in the case of non-applied/non-vocational programs. It is indeed reversed for graduate programs which represent $50 \%$ of abolished/suspended programs, but not for first degree programs as $58.8 \%$ of abolished programs are of applied/vocational nature. The reasons of these mixed results are not clear. It should be noted, however, that the number of program abolition/suspension is low, particularly at the graduate level (3.7\%). The higher percentage of abolition/suspension of undergraduate applied/vocational programs may perhaps be also linked to market adaptation: abolish or suspend those programs that had become obsolete in favor of new revamped more market responsive programs, thus reducing the size of program delivery.

\section{Trends at Université Laval}

As table 2 shows, there were, in the period considered and for first-degree programs, 57 creations of new programs, 35 abolitions/suspensions, and 39 program modifications at Laval University. With respect to graduate programs and for the same period, there were 44 creations of new programs, 6 abolitions/suspensions and 20 program modifications.

Table 2 Undergraduate and Graduate Program changes at Université Laval (1996-2006)

\begin{tabular}{|l|c|c|c|c|}
\hline \multicolumn{1}{|c|}{ Program changes } & $\begin{array}{c}\text { Non-applied/ } \\
\text { non-vocational } \\
(\mathbf{\%})\end{array}$ & $\begin{array}{c}\text { Mixed } \\
(\boldsymbol{\%})\end{array}$ & $\begin{array}{c}\text { Applied/ } \\
\text { vocational } \\
(\mathbf{\%})\end{array}$ & \% (N) \\
\hline \multicolumn{5}{|c|}{ Undergraduate Programs } \\
\hline Creation & 21.6 & 39.2 & 39.2 & $100 \%(57)$ \\
\hline Modification & 23.0 & 41.1 & 35.9 & $100 \%(39)$ \\
\hline Abolition/suspension & 46.4 & 36.6 & 17.0 & $100 \%(35)$ \\
\hline \multicolumn{5}{|c|}{ Graduate Programs } \\
\hline Creation & 12.8 & 35.9 & 51.3 & $100 \%(44)$ \\
\hline Modification & 18.2 & 45.4 & 36.4 & $100 \%(20)$ \\
\hline Abolition/suspension & 70.6 & 17.6 & 11.8 & $100 \%(6)$ \\
\hline
\end{tabular}

In terms of percentage distributions by degree of vocationalization and for first-degree programs, $21.6 \%$ of new programs were non-applied/non-vocational, $39.2 \%$ were applied/vocational, and also $39.2 \%$ were mixed. Concerning abolitions/suspensions of 
programs, $46.4 \%$ of them were non-applied/non-vocational programs, $17.0 \%$ were applied/vocational programs and $36.6 \%$ were mixed programs. As with regards to modifications, $23.0 \%$ of them were of non-applied/non-vocational nature, $35.9 \%$ were of applied/vocational nature, and $41.1 \%$ were mixed.

In the case of graduate programs, $12.8 \%$ of new programs were of a non-applied/non vocational nature, $51.3 \%$ were applied/vocational, and $35.9 \%$ were mixed. Among abolished/suspended programs, $70.6 \%$ were non-applied/non-vocational, $11.8 \%$ were applied/vocational, and $17.6 \%$ were mixed. Of all modifications in the period retained, $18.2 \%$ were non-applied/non-vocational, $36.4 \%$ were applied/vocational, and 45.4\%, were mixed.

One finds a clear pattern of vocationalization at Université Laval with regards to program creation and modification. Of all programs created both at undergraduate and graduate levels, over $80 \%$ were of applied/vocational or mixed domains. In the case of modifications at both levels, $78 \%$ of them were of applied/vocational or mixed types. Finally, the program change behaviour of Université Laval is more consistent in program abolition/suspension: one notes a definite reverse trend in both first-degree and graduate programs: proportionally more undergraduate and graduate programs of non-applied/nonvocational nature were abolished or suspended than either applied/vocational or mixed programs.

\section{Trends at McGill University}

At McGill University, during the 1997-2007 period, there were 128 creations and only 5 abolitions of first degree programs, as well as 294 modifications of existing first degree programs. At $2^{\text {nd }}$ and $3^{\text {rd }}$ cycles, there were 30 creations, two program abolitions/ suspensions and 92 modifications of existing programs (see table 3). 
Table 3 Undergraduate and Graduate Program changes at McGill University (1997-2007)

\begin{tabular}{|l|c|c|c|c|}
\hline Program changes & $\begin{array}{c}\text { Non- } \\
\text { applied/non } \\
\text { vocational (\%) }\end{array}$ & $\begin{array}{c}\text { Mixed } \\
(\%)\end{array}$ & $\begin{array}{c}\text { Applied/ } \\
\text { vocational } \\
(\%)\end{array}$ & $\%(\mathbf{N})$ \\
\hline \multicolumn{5}{|c|}{ Undergraduate Programs } \\
\hline Creation & 18.7 & 35.3 & 46.0 & $100 \%(128)$ \\
\hline Modification & 28.9 & 37.8 & 33.3 & $100 \%(294)$ \\
\hline Abolition/suspension & 40.0 & 40.0 & 20.0 & $100 \%(5)$ \\
\hline \multicolumn{5}{|c|}{ Graduate Programs } \\
\hline Creation & - & 16.2 & 83.8 & $100 \%(30)$ \\
\hline Modification & 39.2 & 31.5 & 29.3 & $100 \%(92)$ \\
\hline Abolition/suspension & - & 100.0 & $100 \%(2)$ \\
\hline
\end{tabular}

Among the created first degree programs, $18.7 \%$ were non-applied/non-vocational, $46 \%$ applied/vocational, and $35.3 \%$ mixed programs. As regards to modifications of existing programs, $28.9 \%$ were of non-applied/non-vocational nature, 33.3\% applied/vocational, and $37.8 \%$ mixed. In the period considered, no $2^{\text {nd }}$ and $3^{\text {rd }}$ cycle non-applied/nonvocational programs were created. In contrast, $83.8 \%$ of them were applied/ vocational and $16.2 \%$ were mixed programs. Concerning modifications of existing programs, $39.2 \%$ were of a non-applied/non-vocational type, $29.3 \%$ applied/vocational, and $31.5 \%$ were mixed. Only two graduate programs were abolished/suspended, and that was in the category of mixed programs.

The tendency towards vocationalization is also found at McGill University in the period considered. Most new programs, at both undergraduate and graduate levels, were of applied/vocational or mixed types. However, with regards to program modification, there is no definite trend as differences are not as important as in the case of program creation.

\section{PROGRAM CHANGES AND DISCIPLINARY SECTORS}

How are program changes (creations, modifications, abolitions/suspensions) distributed among disciplinary sectors? Are there identifiable patterns among disciplinary sectors? Changes by disciplinary sectors will be also analysed for each university starting with Université de Montréal, then Université Laval, and finally McGill University. 
At Université de Montréal, program creations in health sciences are almost all of the mixed and applied/vocational types. This pattern is also found with respect to program modifications. In the case of first degree programs, all program changes in health sciences were of mixed or applied/vocational nature.

In the sector of Pure and Applied Sciences, two thirds of first degree programs were of mixed or applied/vocational types. At the graduate level, five times more applied/ vocational programs were created than non-applied/non vocational ones.

In Social Sciences and Humanities, proportionally more creations and modifications, at first-degree level, were of applied/vocational and mixed types. At graduate level, however, there is a certain balance between changes concerning program creations or program modifications of applied/vocational and mixed types, and non-applied/nonvocational.

Finally in Literary Studies and Arts, it is interesting to note that half of program creations and modifications were of applied/vocational and mixed types.

At Université Laval, the new programs created in the Health Sciences were of applied/vocational nature both at first degree and graduate levels.

In Pure and Applied Sciences, new first degree programs were of mixed types and $80 \%$ of all new graduate programs $(\mathrm{N}=5)$ were of applied/vocational or mixed types. As pertains to program modifications, all were of applied/vocational or mixed nature.

In the field of Social Sciences and Humanities, around two-thirds of first-degree program creations and modifications were of applied/vocational or mixed types. In the case of graduate programs, 8 out of 10 program creations were of applied/vocational and mixed types. Thus, the bulk of changes in this particular field were of practical nature. In the case of program abolitions/suspensions, half were of non-applied/non vocational nature.

In Literary Studies and Arts, half of program creations and modifications were of nonapplied/non vocational type and half of mixed type. It should be noted that a little more than $75 \%$ of program abolitions/suspensions were of non-applied/non-vocational type. 
The bulk of program creations and modifications, at McGill University, were in the fields of Applied Sciences and Social Sciences and Humanities. The changes are found overwhelmingly in first degree programs. As for graduate level programs, one finds a relatively high rate of program changes at the second cycle level (Graduate Diplomas and Master's) comparative to doctoral programs which have experienced relatively few changes.

Program creations are of applied/vocational and mixed types, except in the case of Social Sciences and Humanities sector where around $65 \%$ of creations were of non-applied/nonvocational nature.

Also, a larger proportion of modifications were introduced in Applied Sciences and Social Sciences and Humanities mainly in first-degree programs. Proportionally more modifications were of the mixed type, except in the case of Applied Sciences, where 56\% of them were of applied/vocational type. In Social Sciences and Humanities, there is a certain balance in program modifications between mixed and non-applied/non-vocational types.

\section{DISCUSSION}

When we compare the program change behaviour of these three research intensive universities during the selected ten-year period, can we find a recurrent pattern or do these universities follow particular paths? What are then the similarities and differences in program change behaviour at both undergraduate and graduate levels? In the case of the creation of first degree programs, Université Laval stands behind Université de Montréal and McGill University: these latter two institutions created at least twice as many programs as the former It is striking, however, that with regards to abolition/suspension of programs, McGill University abolished only a few of them $(\mathrm{N}=5)$, whereas the two Francophone universities closed or suspended around six times more programs. Also, McGill University introduced in its first-degree program twice as many modifications as the two Francophone universities together. 
The pattern of graduate program changes does not follow that of first-degree programs. For graduate programs, Université de Montréal created at least four times more programs than McGill University and Université Laval. With regards to program abolition/suspension, McGill University has been very reluctant to follow such policy (only two programs). On the contrary, the two Francophone universities together abolished or suspended seventeen programs. As for modifications, both Université de Montréal and McGill University exhibit a similar pattern: these two institutions introduced in their existing programs about five times more modifications than Université Laval.

What is the "program change" behaviour pattern of these three institutions as pertains to degree of vocationalization? In program creation of first degree applied/vocational programs, the three institutions show a similar pattern: the percentage of program creation of this type fluctuates around $40 \%$ of all created programs. In terms of applied/ vocational modifications of existing programs, McGill and Université Laval show the same pattern (around 35\%), Université de Montréal departs from this pattern as $50 \%$ of all modifications are of that type. However, combining the modifications of both applied/vocational and mixed types, the percentages are in the range of $70 \%(71.7 \%$ McGill; 70.7\% Université de Montréal; 77\% Université Laval).

It is interesting to note that, in the case of graduate studies, all created programs at McGill University were of applied/vocational and mixed types, whereas in the case of Université de Montréal around a third of all created programs were of that type. In the case of Université Laval, the comparative figure is 1 in 10 of all created programs. If one considers modifications of existing programs, McGill University and Université de Montréal show similar patterns: around $60 \%$ of all modifications introduced were of applied/vocational or mixed types. The corresponding figure for Université de Laval is $87 \%$. It should be noted, however, that, a sizable proportion of modifications introduced by Université de Montréal and McGill University in their graduate programs were of non-applied/non-vocational nature (40\%). Finally with regard to abolitions/suspensions, at least $50 \%$ of all abolished/suspended programs of Université de Montréal and 
Université Laval were of the non-applied/non-vocational type. As noted above, program abolition/suspension is not common at McGill University.

Is there a trend in program changes when comparing program change behaviour by disciplinary sector in these three research intensive universities? In all fields, except in the Literary Studies and Arts sector, there are proportionally more program creations and modifications of mixed or applied/vocational nature. This trend is found in the three cases, except for social sciences and humanities at McGill University, where two thirds of program creation were of non-applied/non vocational nature. In the case of Université Laval, even in the literary studies and arts sector, half of the program creations and modifications were of "practical" nature.

Thus, there appears to be a trend towards vocationalization in these three research intensive universities. However, one notes a major difference among them. Whereas Université de Montréal and Université Laval have created new programs or modified the existing ones in the direction of vocationalization at both undergraduate and graduate levels (Diploma, Master's and Ph.D.), McGill University's trend toward vocationalization is found mainly in first-degree programs and, secondly, in $2^{\text {nd }}$ cycle level programs, but not in Ph.D. programs. Also, McGill has introduced relatively more new undergraduate social sciences and humanities programs (65\% of all program creations) of non-applied/non-vocational nature.

\section{GRADUATE TRAINING AND VOCATIONALISM}

The past fifteen years have seen a steady increase in bisectorial (university/industry) and/ or multisectorial (government/university/industry/not-for-profit organizations) research and development activities that have been analyzed by many. Blumenthal et al.(1986), Gibbons et al. (1994), Slaughter \& Leslie (1997), Clark (1998, 2003), Etzkowitz \& Webster (1998), Daza-Campbell \& Slaughter (1999), Etzkowitz \& Leydesdorff (2000), Fisher \& Atkinson-Grosjean (2002), Gumport (2002), Geiger (2004), Slaughter \& Rhoades (2004), Turk-Bicakci \& Brint (2005), Crespo \& Dridi (2007), Jain \& Maltarish (2009), Metcalfe (2010), Viale \& Etzkowitz (2010), Kauppinen (2012), Ramos-Vielva \& Fernández-Esquinas (2012) to name a few, have scrutinized the phenomenon and its 
impact on contemporary academia. However, further thought needs to be given to the impact of these collaborations on teaching, particularly on graduate teaching, and on the training of graduate students for research. At this particular moment, what seems obvious is that these new activities and their impact on academia are easily justified by the prevailing view of what university is and should remain, whether this traditional view is found on paper or in commentary:

I don't think there is any ambivalence at our university about professional programs. Our mission is about excellence in teaching, in research and in service. And this third aspect, service to society, implies that we are prepared to make a contribution and clearly preparing individuals for professions is an important contribution to society at large as well as a contribution to the individual who is receiving the training. (Deputy Provost)

However, this easy recuperation of phenomenon does not prevent the question of the impact of these collaborations on academia, especially on teaching and training for research, to arise.

\section{An obvious reality?}

This spontaneous comment, offered at the beginning of an interview by an insightful professor of Pharmacology is revealing of the attitudes of many actors and forces in academia today:

More and more, I see students who want an easy life, an easy degree: get in, get out, get a good job and you are set for life. They are more goals oriented but it is not in a positive way, or what I consider a positive way (it's subjective). Are there more short term diplomas? Yes absolutely. In Québec, universities get more money from the government out of creating short programs. So they are prone to do that. In our field, there is a clear need in the industry for that. The pharmaceutical industry, more often than not, will hire three or four Master's for one Ph.D. Ph.Ds are overqualified and they are too expensive. If you are graduating too many $\mathrm{Ph}$.Ds you are wasting your time and your money: and not all of them are good. A company would rather pay a good Master's than a bad or even a good Ph.D. because they are overqualified. They can't take a Ph.D. and make him do a technician's job and pay him the salary of a Ph.D. So they tend to look for people with "Certificates" or "Diplomas" and eventually Master's. So in our field, the recent trend toward short programs serves everybody: the government, the university, the industry and the students who want short programs and an easy access to the job market. (Professor, Pharmacology) 
This new reality trickles into academia in many ways one of them being the bisectorial and multisectorial collaborations between scholars (university professors and graduate students) industry and government. However these collaborations do not change the way professors teach the fundamentals of their discipline as illustrated by these comments:

Collaboration with industry doesn't change anything in terms of how we prepare graduate students. It is all about sound science for me. The question is that the research has to be done properly and rigorously. My collaborations with industry haven't changed anything about experimental design or my philosophical approach to science. A firm understanding in basic research is the most important thing. Once you have got that you can step laterally into more applied fields. (Professor, Zoology)

Or still:

I teach fundamental research and any good fundamental research will encourage innovation: the creation of new concepts or the creation of new products. (Professor, Biology)

Or again:

I will tell you, in my experience industry wants exactly the same things as academia wants. It wants really smart, hardworking people who can think. I can't make them any smarter than they are, and I can't make them anymore hardworking than they are, so what I am trying to do is teach them how to think. I want them to think out of the usual rubbish that in my opinion is usually taught in University where somebody gets up, peddles out a bunch of facts that the students scroll out on a piece of paper and basically that is it. I am trying to get them to think a bit more: a) at the graduate level, about what is in a publication and what it all means and how people came up with the ideas they came up with and b) at the undergraduate level, I am teaching them how to deal with information coming from multiple sources and how to deal with the inconsistencies in the information and how to work their way through that. And I believe that that skill of collecting information and organizing it and presenting it is a skill that is not really scientific but it is just a general skill that is good for the job market. (Professor, Microbiology and Immunology)

They seem to impact teaching and the training of graduate students for research indirectly, in two different way: a) by transmitting of leading edge information and techniques they have accessed because of their collaborations with industry or the networks and, most importantly, b) by the handing down of values, more often than not productivist, gathered through the professor's contacts with industry, to students more than willing to accept them without much examination. 


\section{Cutting edge information in contemporary academia}

The most obvious and probably less insidious 'spilling over' from industry to classroom is the transmitting of information - leading edge information - gathered by the professor while collaborating in a bisectorial or multisectorial research project. This type of information pertains to the discipline itself and to the needs of industry (job opportunities) the professor readily identifies and passes on to his students:

Because of the particular area that I am involved in, which is designing integrated circuits, I can bring to the classroom the problems that I see in industry. I can tell the students: 'These are the problems they are still facing in industry. This company makes this product and it works at such and such a speed. Along comes another company and they have managed to make a similar product work at higher speed: why?' I don't name the companies and I try to keep things at a generic level, but these experiences certainly influence both my undergraduate and my graduate teaching. (Professor, Electrical Engineering)

Or again:

I'm a bit more broad now that I have been involved in the networks. It makes it easier for me to teach some things that I wouldn't be good at otherwise. I'm teaching a lot more stem biology and inflammatory models than I would have if I hadn't been involved in the network. I have a better feel for what is really cutting edge research and I have a good idea of what are the good places to go whether in industry or academia. I also encourage my students to work in applied research fields and I have a better feel for what is marketable industrially. (Professor, Medical Genetics)

Or still:

My collaborations with industry have often been about repair and rehabilitation of older structures and I do encourage them in my graduate training. I know industry needs people in that field and I encourage my students specialize there. (Professor, Civil Engineering)

But as one interviewed professor so aptly put it: "What happens if you prepare your students for certain jobs and a certain market and that market changes abruptly like it so often has in the past?" Thus the importance on training students in good, quality, fundamental research that almost every professor interviewed considered an essential priority. But the examination of the impact of bilateral and multilateral collaborations of academics with industry must take into account much subtler phenomena, the handing down of, more often than not, undetected productivist values. Wittingly or unwittingly, 
professors pass on to students who are more than willing to accept them, values that make industry what it is. Indeed, many a professor has noticed that floundering graduate students, once integrated in a project involving industry, could suddenly become top performers, quite excited about the 'hot' project they had become involved in. Master's degree students were more apt to get involved in an uncritical fashion in these projects:

We had two Master's students who were the main thrust of the project. They sort of took ownership of the project and were really excited because they were in the early stages of their career and could see that the overall goal was application to industry. I find students are more interested in research that has application because they can wrap their head around it. They realize that this is important for the same reasons that the general public would be more likely to support research that is applied in nature. (Professor, Zoology)

Indeed, the credibility of the professor, often a top level academic and scholar, can actually be enhanced, in the eyes of his students, by his collaboration with industry:

As a teacher I really value my collaboration with industry because it broadens my knowledge base and my professional experience levels. And I can rely on these experiences in delivering information in a way that is interesting and informative. You can write your book chapters and publish your papers and obtain a lot of respect from students that way, but I think if you show some practicality, some real life applications, it's very powerful for the students because it is reality. It's one thing to take students in the lab, where there are a bunch of chemicals and test tubes and tell them: 'Well today we are going to make this or that chemical reaction...'. It's another thing to say: 'Here are some pigments... Let's see if we can put them in a formulation that someone would buy or be interested in from a market point of view'. The association with practicality is closer to them than the commitment to learn a technique from a scientific point of view or an academic point of view. (Professor, Food Nutrition and Health)

So what are these values trickling in academia, by what means are they transmitted and what are their impact on teaching and training of graduate students? A casual examination identifies four: practicality, collaboration, interdisciplinarity and entrepreneurship.

\section{New values in contemporary academia}

Of all values transmitted from industry, to academia, by means of bisectorial or multisectorial collaborations, the one most often referred to by professors is a sense of practicality: 
The way I define what I do has changed a lot. When I started I was a University professor, a basic scientist trying to unravel the mysteries of Biology. And I am still doing that but I see a more important role now for me which is to make discoveries that will lead to an improvement in health care. It gives me a sense of accomplishment. To be honest, I didn't really believe, when I started this for a living, that I would make discoveries that would translate into treatments. That is exactly what has happened and it is incredibly exciting. (Professor, Neurology)

This sense of practicality is both professional and commercial and has appeared in the classroom, or lab, in the past decade:

I have about four graduate students and I must say that in two cases the goal of the work is to develop a therapy and in the other two we are always thinking of the potential for intellectual property, something that may be of value, that may be commercializable or of use in the clinic. It certainly is a constant part of my everyday thinking. That wasn't true before. That has changed enormously with my understanding of how things work. (Professor, Biochemistry)

It is transmitted by academics and by representatives of industry that professors invite into the classroom:

I am an academic person, I am not an industry person, so I give the global view of a problem and then I bring in the VP of Astra Zeneca or Methyl Gene or Pfizer and so on and they give a view of their side. They talk about their experience: this is how we developed this drug that today you can buy at Pharmaprix. This way, students see how things are done and they also see the differences: Pfizer does it in a way and Merck does it a different way. (Professor, Pharmacology)

Or again:

The one thing that I do to involve industry in my teaching is to have more industry figures who come over to speak. They teach a seminar in one of my classes for example (Professor, Civil Engineering)

And still:

Because of my contacts with industry I can recruit people from all around Vancouver and get them to teach a certain number of classes. They provide diversity. The thing is not everybody addresses things the same way and not everybody's style is suitable for somebody else. The idea is that students can see enough different approaches and they can develop their own style. (Professor, Microbiology)

And, how can one be practical without being collaborative. Excessive competitiveness is time consuming, resource consuming and all around costly. In a globalized economy, 
where the locus of competition has been displaced (from national to international) and its intensity has been heightened, competition, in its less intense loci (national/regional) is being replaced as a value by collaboration. Many interviewed professors have stressed its importance:

I think we teach people how to be more collaborative than competitive as a general rule. These problems we deal with are really difficult problems, and when it comes down to it, science advances very quickly. So when you have a problem, you can spend a year doing the tests that will provide an answer to your question or, if there is a world expert that can do the work in two weeks, you can contact him, get the answer and move on. (Professor, Medical Genetics)

And again:

With each of these networks there is a bit of an education process. Normally as a professor I am working as an individual and every other professor is potentially a competitor. Even within Canada, papers get awarded to the person who does the work first. You don't get prizes for coming in second place! When you join the networks you don't get a lot of money unless you put in a collaborative proposal with a bunch of professors from different areas of Canada. So you are forced to collaborate. And what that means is that you have to show all your data to your colleagues before it is published and that is a bit of a change in the thought process for an individual. A lot of people are leery of showing their unpublished work to others who could potentially compete with them. So it takes about a year or two for a person to actually buy in, but once you do, you are a hell of a lot more productive than if you were working on own. Once you realize that what you share with people they share back with you, and you are all putting it forward for a bigger goal, it starts going really well. (Professor, Medical Genetics)

This emphasis on collaboration takes an even deeper meaning with the focus on interdisciplinarity brought about by both the bisectorial and the multisectorialcollaborations:

The reason that we are so successful here is that we have learnt so much about how other disciplines think about problems and we have brought that to obstetrics. It gives us a tremendous edge. If you keep thinking about a problem the same way, you will end up against the same brick wall that everybody else did because you have exhausted the capacity of that way of thinking. What we are looking for in our company are what we call ' $T$ ' people: people who have a deep understanding of a problem but who also bring a wide perspective to their work because of other experiences. Let me tell you about the people that we have here. I'm certainly an obstetrician but since the company has been created I feel that I've become fairly amateur mathematician and engineer. I understand the lingo quite well. I understand how they think. It has revolutionized how I think about our problems. The 
lady who is in charge of marketing has a degree in Fine Arts and an MBA. So our software is very pleasing to look at and easy to use. My right hand person is a Biomedical Engineer. He can discuss physiology as well as Electrical Engineering. Then we have a gentleman who has worked in telecommunications because of signal processing on telephones and we work with signals coming from baby's heart beats. We have a person in charge of product management, her background is in 'intensive care' nursing but she also happens to have a Computer Engineering degree. They are all very qualified people but see how broad their expertise is. Again, our CEO is someone who has had several careers in different areas and she is fabulous. This ability to see things beyond the traditional way is what has made us because each of these people sees things a bit differently and have something to contribute. (Professor, Obstetrics)

Beyond practicality, collaboration and interdisciplinarity lies the ultimate value that is penetrating contemporary academia: entrepreneurship. It is entering universities by way of programs, often short programs in entrepreneurship, by the offices of technology transfer, and by the bisectorial and multisectorial collaborations of academics and scholars. In addition to collaboration with industry through contracts, creating their own companies or participating in an NCE projects, professors encourage students to acquire entrepreneurial know-how when it is available:

I have two graduate students and a post doc student that I have taken with me on the NCE project. They have already attended two meetings that the network has organized and they are participating on a bi-monthly basis in some of the trainee programs that the networks has. The network has been involved in teaching them how to set up companies: how do you get involved in filling patents, how do you write your first grant application etc. They have a lot of training activities associated with the network towards future careers and they get the students involved as quickly as they can.

That these values are penetrating academia seems obvious. And whether they are good or bad, right or wrong, is irrelevant. What is essential though, is that they remain unchallenged. Traditionally, students arriving in academia would bring with them, not only the dominating values of their time, but also, the level of insight, or lack thereof, accompanying these values. As they climbed the rungs of the academic ladder these values would slowly be transformed -in some cases radically changed-into a deeper understanding, an increased awareness, not only of their respective disciplines but of most problems they had to face. A thought maturation process had taken place, as one professor has put it earlier: they had learned how to think in a critical fashion. What now 
seems to be happening is that dominating values penetrating academia go unchallenged.

The student/scholar encounter seems to be a 'value reinforcement' process rather than the challenging of fundamental beliefs and attitudes.

As for science itself, the efficiency of scientific knowledge and the application of its discoveries, many a professor, however grateful they may be for the opportunity to participate in the bisectorial or multisectorial collaborations, remain somewhat unconvinced of the long term benefits of this new way of "doing business":

I'm very appreciative of the opportunities that are presented by working on these more applied projects. But I think that one of the things that is lost, as universities and the general public's perception of research move more and more to industrially applied and relevant research programs, is that we are shortchanging basic research. The beauty of applied research is that it is goal directed and it can be put into operation and ultimately make money which is the bottom line, that's what industry strives on. But all the innovations, the things that are going on now, are based on the basic research that was done $20,50,80$ years ago. If you think of the basic research there is probably $80 \%$ of it that maybe nobody will ever pay a lot of attention to but there is also $20 \%$ of it that really revolutionizes our society And I think that what we will find, is that by diverting money from basic research toward applied, we may see an instant boom in industrially relevant areas, but the investment in our future is greatly reduced. (Professor, Zoology)

And still:

Directed research is an interesting thing. I think the person working on asthma today is going to be the person who cures cancer tomorrow. You set out doing one line of research and you make a discovery that is actually more applicable to a different field. I think that happens all the time and I'm a real big believer in undirected research: let people work on what they want to work on and great ideas for all the diseases follow. On the other hand, that is certainly not what governments want to hear. If you take a look at CIHR or NIH or any other government agency, they are really pushing for directed research these days and their idea is that the public wants to see a direct return on what they have invested in. Unfortunately, I don't think it's the best way to do it. But if it means more money in the system, then that is going to help. If that's what they tell us to do, then that is what we will guide our research towards, but I honestly believe that just fundamental basic research is more likely to give you cures to diseases than really heavily focused directed research. And I would argue that throwing hundreds of billions of dollars at the HIV infection still hasn't produced a cure. We still haven't found a vaccine: it's a small virus that causes a hell of a lot of trouble and we've invested in it for twenty years. And the returns haven't really been there. I 
think most of the good stuff on HIV may have come out through basic research or something else that would have turned out to be applicable.

As for the ultimate impact of the bisectorial and multisectorial collaborations on teaching, one can observe a few sideslips: of all professors interviewed, one has completely stopped teaching so as to be constantly available for the company that has been created with her idea (at the investor's demand), and two others are 'buying out' of their teaching responsibilities with the money made at the company, one being released of half of his duties, the other of one third. And, sadly, some professors seem more committed to their entrepreneurial activities than they are to academic pursuits:

We had a dispute about a student who thought he should have been paid more for the time that he had been involved in a project under the NCE umbrella where the student felt the work had been commercialized without any benefit to himself. He also felt he hadn't been supervised properly, his professor being more interested in commercializing the results of the research than fostering the student's career. He didn't get proper guidance and proper support. That was a difficult case and I'm still not happy with the way it has been resolved. (Professor, Computer Science)

\section{CONCLUDING REMARKS}

This paper has tackled the question of the vocationalization of the university from the supply side of the equation. It has analyzed university program changes in a ten-year period, and has discussed some values transmitted to graduate students by professors involved in university- industry-government collaborative research projects. The data gathered in this study reveal a discernible tendency towards vocationalization, of academic programs and graduate training, which confirms previous research results from a variety of higher education contexts. In other words, the data gathered appear to accredit the "convergence" hypothesis (Bleiklie, 2005), at least in the universities of the study. This convergence is more remarkable as the four higher education institutions of the study are of the research intensive type. One would expect that these universities be less inclined to question the traditional values of a liberal education and of an altruistic pursue of truth, independently of constraints emanating from the social and economic environment. On the contrary, the arguments found in Senate Minutes regarding program changes are that of the relevance of the changes for labour market needs. Expressions 
like "the value of this course for securing a job", "the understanding of more areas for a broader job market" "[program] targeted [to] respond to changes in the market place", "there is a strong market in this area for a Master's level program" and other similar to these, present the program changes in a perspective of preparing students for market demands, that is, promoting relevant arrangements for individual and societal needs.

If our data are valid, and there is no reason to believe they are not, we are witnessing a trend towards a "utilitarian ethos" (Brint, 2002) of university training. It seems that the "old" relevance, that which universities deemed right for the good of the beholder, is changing in a significant way. The new relevance could be interpreted by segments of the academic community as a sort of "treason": a negation of the values of liberal education and of altruistic research. But as Neave (2006) aptly discussed in his last editorial of Higher Education Policy, relevance, as treason à la Monsieur de Talleyrand-Périgord, is "simply a question of dates". What was relevant at one time becomes irrelevant at another time: "yesterday's "curricular match" becomes today's "qualification mismatch" (Neave, 2006, p. 401). According to him, the Bologna Declaration (1999) uses a language that underlines the role of the university in ensuing economic strength and competitiveness through the production of skilled workers. For Neave (2006) the implications of this drift have far reaching consequences:

The drive towards vocationalization and the push toward the universities assuming full responsibility for the development of research-based technologies amount to little less than redefining the mission of the university in terms of those very priorities that earlier generation of policy-makers assigned to the non-university sector of yesterday. (p. 408)

The question that is debatable is whether this is a "good" development or not. Or, better than a simple yes or no answer to this question, the issue is to ascertain how to preserve the "Idea of a University" (the liberal tradition of knowledge and personal development) in a context of "externalization" (Kogan, 2006) and engagement in the social and economic development of one's society. 


\section{REFERENCES}

Adamuti-Trache, M, Hawkey, C, Schutze, H.G. \& Glickman, V. (2006). The labour market value of Liberal Arts and Applied Education Program: Evidence from British Columbia. Canadian Journal of Higher Education/Revue canadienne de l'enseignement supérieur, 36(2), 49-74.

Ayalon, H. \& Yogev, A. (2005). Field of study and student's stratification in an expanded system of higher education: The case of Israel. European Sociological Review, 21, 227241.

Arum, R., Gamoran, A., \& Shavit, Y. (2007). More inclusion than diversion: Expansion, differentiation, and market structure in higher education. In Y. Shavit, R. Arum \& A. Gamoran (eds.). Stratification in Higher Education: A Comparative Study. Stanford, CA: Stanford University Press.

Barnett, R. (1990). The Idea of Higher Education. London: SRHE and Open University Press.

Barone, C. et Ortíz, L. (2011). Overeducation among European university graduates: A comparative analysis of its incidence and the importance of higher education differentiation. Higher Education, 61, 325-337.

Barrell-Damian, L., Brown, T., Dearing, A., Font, J., Hagen, S., Metcalfe, J. \& Smith, J. (2010). Collaborative doctoral education: University-industry partnerships for enhancing knowledge exchange. Higher Education Policy, 23, 493-514.

Bash, L. (2009). Education, Jobs, and vocational training. In Cowen, R. \& Kazanias, A. (eds). International Handbook of Comparative Education. Dordrecht: Springer Science \& Business Media, B.V., p. 539-550.

Bastedo, M.N. \& Gumport, P. (2003). Access to what? Mission differentiation and academic stratification in US public higher education. Higher Education, 46, 341-359.

Birnbaum, R. (1983).Maintaining Diversity in Higher Education. San Francisco: JosseyBass.

Bleiklie, I. (2005). Organizing higher education in a knowledge society. Higher Education, 49(1), 31-59.

Blumenthal, D., Gluck, M, Louis, K.S. \& Wise, D. (1986) University-industry research relationships in biotechnology: Implications for the university Science, 232(4735), 242246.

Brint, S., Riddle, M., Turk-Bicakci, L. \& Levy, C.S. (2005). From the Liberal to the Practical Arts. American Colleges and Universities: Organizational Analysis and Curricular Change. The Journal of Higher Education, 76(2), 151-180. 
Brint, S. (2002). The rise of the 'practical arts'. In S. Brint (ed.). The Future of the City of Intellect: The Changing American University (p. 231-259). Stanford: Stanford University Press.

Clark, B.R. (1998). Creating entrepreneurial universities: Organizational pathways of transformation. Oxford: Pergamon.

Clark, B.R. (2003). Sustaining change in universities: Continuities in case studies and concepts. Tertiary Education and Management, 9, 99-116.

Côté, J.E. \& Allhar, L. (2011). Lowering Higher Education: The Rise of Corporate Universities and the Fall of Liberal Education. Toronto: University of Toronto Press.

Crespo, M. (2006). L'université se professionnalise-t-elle au Canada? Une analyse longitudinale des choix de programmes de formation. Paper presented at «Enjeux et défis des sociétés de la connaissance au Canada et dans l'Union Européenne. Transformations des universités ». Bruxelles, Université libre de Bruxelles, March 22-24.

Crespo, M. \& Dridi, H. (2007). Intensification of university-industry relationships and its impact on academic research. Higher Education, 54, 61-84.

Dennison, J.D. \& Schuetze, H.G. (2004). Extending access, choice, and the reign of the market: Higher education reforms in British Columbia, 1989-2004. Canadian Journal of Higher Education/Revue canadienne de l'enseignement supérieur, 34(3). 13-38.

Daza-Campbell, T.I. \& Slaughter, S. (1999). Faculty and administrators' attitudes toward potential conflicts of interest, commitment, and equity in university-industry relationships The Journal of Higher Education, 70(3), 309-352.

Eicher, J.C. (2001). Évolution et problèmes de l'enseignement supérieur en Europe. Séminaire international Débat interculturel sur l'évaluation des systèmes éducatifs. Université Mentouri, Constantine, October 29-31.

Eicher, J.C. (1999). Jusqu’où faut-il professionnaliser? Societal, 26, 79-83.

Enders, J. (2005). Border crossings: Research training, knowledge dissemination and the transformation of academic work. Higher Education, 49, 119-133.

Etzkowitz, H, \& Leydesdorff, L. (2002). The dynamics of innovation: From national systems and Mode 2 to a triplex helix of university-industry-government relations. Research Policy, 29, 109-123.

Etzkowitz H. \& Webster, A. (1998) Entrepreneurial Science: The second academic revolution. In H. Etzkowitz, A. Webster \& P. Healey (eds), Capitalizing Knowledge. New Intersections of Industry and Academia (11, 21-46). Albany: State University of New York Press.

Fisher, D. \& Atkinson-Grosjean, J. (2002). Brokers on the boundary: Academy-industry liaison in Canadian universities. Higher Education, 44, 449-467. 
Fisher, D., Rubenson, K., Jones, G. \& Shanahan, J. (2009). The political economy of post-secondary education: A comparison of British Columbia, Ontario and Québec. Higher Education, 57, 549-566.

Gallagher, P. (1990). Community Colleges in Canada: A Profile. Vancouver: Vancouver Community College Press.

Gemme, B. \& Gingras, Y. (2004). Training a new breed of researchers inside and outside universities. Working paper presented at Colloquium on Research and Higher Education Policy. Paris: UNESCO.

Geiger, R.L. (2004) Knowledge and Money: Research Universities and the Paradox of the Market Place. Stanford: Stanford University.

Gibbons, M., Limoges, C., Novotny, H., Schartzman, S., Scott, P. \& Trow, M. (1994). The New Production of Knowledge: The Dynamics of Science and Research in Contemporary Societies. London: Sage.

Grubb, W.N. \& Lazerson, M. (2005). Vocationalism in Higher Education: The triumph of the education Gospel. The Journal of Higher Education, 76(1), 1-25.

Gumport, O.J. (2002). Universities and knowledge: Restructuring the city of intellect. In S. Brint (ed.), The Future of the City of Intellect: The Changing American University (p. 47-81). Stanford: Stanford University.

Irvine, J. \& Martin, B.R. (1984). Foresight in Science. Picking the Winners. London: Frances Printer.

Jain, S. \& Maltarish, M. (2009). Academics or entrepreneurs? Investigating role identity modification of university scientists involved in commercialization activity. Research Policy, 38, 922-935.

Jones, G.A. (2004). Ontario higher education reform, 1995-2003: From modest modifications to policy reform. Canadian Journal of Higher Education/Revue canadienne de l'enseignement supérieur, 3(2), 39-54.

Kauppinen, I. (2012). Towards transnational academic capitalism. Higher Education, 64, 543-556.

Kerr, C. (1963). The Uses of the University. Cambridge: Harvard University Press.

Kitagawa, F. \& Oba, J. (2010). Managing differentiation of higher education system in Japan: Connecting excellence and diversity. Higher Education, 50, 507-524.

Kogan, M. (2006). The European research university: An historical parenthesis? Higher Education Policy, 19(3), 397-399

Kyvik, S. \& Olsen, T. (2008). Does the aging of tenured academic staff affect the research performance of universities? Scientometrics, 76, 439-455.

Levin, J.S. (2004). The community college as a baccalaureate-granting institution. Review of Higher Education, 28(1), 1-22. 
McLaughlin, P. \& Mills, A. (2011). Combining vocational and higher education studies to provide dual parallel qualifications. Journal of Further and Higher Education, 35, 233-245.

Marshall, D. (2004). Access to degrees in the knowledge economy. Policy Options, 25(7), 76-82.

Marshall, D. (2008). Differentiation by degrees: System design and the changing undergraduate environment in Canada. Canadian Journal of Higher Education/Revue canadienne de l'enseignement supérieur, 38(3), 1-20.

Meek, V.L., Huisman, J. \& Goedegebuure, L. (eds) (2000). Diversity, Differentiation, and Markets. Special issue of Higher Education Policy, 13(1).

Mendoza, P. (2007). Doctoral students socialization: A case study. The Journal of Higher Education, 78, 71-96.

Metcalfe, A.S. (2006). Revisiting academic capitalism in Canada: No longer the exception. The Journal of Higher Education, 81, 489-514.

Morphew, C.C. (2009). Conceptualizing change in the institutional diversity of US colleges and universities. The Journal of Higher Education, 80(3), 243-269.

Neave, G. (2006). Monsieur de Talleyrand-Périgord qualities. Higher Education Policy, 19, 401-409.

Powell, J.J.W., Bernhard, N. \& Graf, L. (2012). The emerging European model in skill formation: Comparing higher education and vocational training in the Bologna and Copenhagen Processes. Sociology of Education, 85, 240-258.

Powell, J.J.W., Graf. L., Bernhard, N., Coutrot, L. \& Kieffer, A. (2012). The shifting relationship between vocational and higher education in France and Germany: Towards convergence? European Journal of Education, 47, 405-423.

Ramos-Vielva, I. \& Fernández-Esquinas, M. (2012). Beneath the tip of the iceberg: Exploring the multiple forms of university-industry linkages. Higher Education, 64, 237265.

Rhodes, F. (2001). A battle plan of professors to recapture the curriculum. The Chronicle of Higher Education, September 14.

Salminen-Karlsson, M. \& Wallgren, L. (2008). The interaction of academic and industrial supervisors in graduate research. An investigation of industrial research schools. Higher Education, 56, 77-93.

Slaughter, S. Archer, C.J. \& Campbell, T.I.D. (2004). Boundaries and quandaries: How professors negotiate market relations. The Review of Higher Education, 28, 129-165.

Slaughter, S. \& Rhoades, G. (2004). Academic Capitalism and the New Economy. Markets, State, and Higher Education. Baltimore and London: The John Hopkins University Press. 
Slaughter, S. \& Leslie, X. (1997). Academic capitalism: Politics, Policies and the Entrepreneurial University. Baltimore: John Hopkins University Press.

Slaughter, S. Campbell, T., Hollerman, M. \& Morgen, E. (2002). The "traffic" in graduate students: Graduate students as token of exchange between academe and industry. Science, Technology, and Human Values, 27, 282-313

Smelser, N. (1974). Growth, structural change, and conflict in California public higher education. In N. Smelser \& G.A. Almond (eds), Public Higher Education in California (p. 9-141). Berkeley, CA: University of California Press.

Smith, D. (2005). Liberal Arts vs. applied programming: the evolution of university programs in Manitoba. The Canadian Journal of Higher Education, XXXV.

Teichler, U. (2001). Changing patterns of the Higher Education system and the perennial search of the second sector for stability and identity. Millenium, 21.

Teichler, U. (2006). Changing structures of the higher education systems: the increasing complexity of underlying forces. Higher Education Policy, 19, 447-461.

Teichler, U. (2008). Diversification: Trends and explanations of the shape and size of higher education. Higher Education, 56, 349-379.

Teixeira, P., Jongbloed, B., Amaral, A. \& Dill, D. (eds) (2004). Markets in Higher Education. Rhetoric or Reality? Dordrecht: Kluwer.

Teixeira, P., Rocha, V., Bisaisa, R. \& Carodoso, M.F. (2012). Competition and diversity in higher education: An empirical approach to specialization patterns of Portuguese institution. Higher Education, 63, 337-352.

Thune, T. (2009). Doctoral students on the university -industry interface: A review of the literature. Higher Education, 58, 637-651.

Van Vught, F.A. (2008). Mission diversity and reputation in higher education. Higher Education Policy, 21, 151-174.

Viale, R. \& Etzkowitz, H. (eds) (2010). The Capitalization of Knowledge: A Triple Helix of University-Industry-Government. Northampton, MA: Edward Elgar Publishing.

Walters, D. (2006). An examination of the school-to-work transitions of male and female college and university graduates of Applied and Liberal Arts programs in Canada. Higher Education Policy, 19, 225-250.

Williams, G. (1985). Graduate employment and vocationalism in higher education. European Journal of Education, 20(2), 181-192. 